\title{
The Bee Chromosome database (Hymenoptera: Apidae)
}

\author{
Marina Souza CunhA ${ }^{1}$, Danon Clemes Cardoso ${ }^{2}$ (D) , Maykon Passos Cristiano ${ }^{2}$, \\ Lucio Antônio de Oliveira CAmpos ${ }^{1}$, Denilce Meneses Lopes ${ }^{1}$ \\ ${ }^{1}$ Laboratório de Biologia Molecular de Insetos, Departamento de Biologia Geral, Universidade Federal de Viçosa, \\ Campus Viçosa, Av. P.H. Rolfs s/n, Viçosa, Minas Gerais CEP 36570-900, Brazil \\ ${ }^{2}$ Laboratório de Genética Evolutiva e de Populações, Departamento de Biodiversidade, Evolução e Meio Ambiente, \\ Universidade Federal de Ouro Preto, CEP, Ouro Preto, Minas Gerais 35400-000, Brazil
}

Received 7 June 2020 - Revised 7 December 2020 - Accepted 16 December 2020

\begin{abstract}
The bee diversity (Apidae) estimative ranges from 18,000 to 20,000 species worldwide. Together, they show an impressive diversity in morphological, ecological, and behavioral traits, and there is still much to be understood about their taxonomy and systematics. Their chromosome count variability and genome biology are also astonishing. To date, around 200 bee species have already been karyotyped, with chromosome numbers varying from $n=3$ to $n=28$, and nuclear haploid genome sizes are available for approximately 70 species with a variation of $1 \mathrm{C}=0.19 \mathrm{pg}$ to $1 \mathrm{C}=1.38 \mathrm{pg}$. The Bee Chromosome database was created (www.bees.ufop.br) to summarize the Apidae cytogenetic knowledge by assembling all the cytogenetic information published on bees. Considering the importance of cytogenetic studies for taxonomy, phylogeny, genetics, systematics, conservation, and evolution, the main goal of this database is to outline the advances in the field of bee cytogenetics over the last century.
\end{abstract}

\section{chromosomal evolution / chromosome number / cytogenetics / karyotypic formula / nuclear genome size}

\section{INTRODUCTION}

Bees are an important insect group represented by one family, Apidae Latreille, 1802, which is comprised of seven subfamilies: Andreninae, Apinae, Collectinae, Halictinae, Megachilinae, Melittinae, and Stenotritinae (Melo and Gonçalves 2005). Together, they represent between 18,000 and 20,000 species described worldwide (Michener 2007). A variety of species are good honey producers, and their pollination services play an important role in the ecosystem and human agriculture (Michener 2007; Roubik et al. 2018). Their morphological, ecological, and behavioral diversities are remarkable, and there is

Corresponding author: D. Cardoso,

danon@ufop.edu.br;

D. Lopes, denilce.lopes@ufv.brM. Lopes,

denilce.lopes@ufv.br

Manuscript editor: Cedric Alaux still much to be understood about their taxonomy, systematics, and evolution (Moure et al. 2007; Sedivy et al. 2013; Kapheim et al. 2015; Shell and Rehan 2018).

Databases provide a virtual space to store data on specific topics that can later, with cumulative information, be used to visualize patterns and produce useful knowledge (Fayyad et al. 1996). A range of databases have been created to compile different aspects of genetic data: cytogenetic information (Berrar et al. 2001; Vulto-van Silfhout et al. 2013; D'Ambrosio et al. 2017; Cardoso et al. 2018a; Perkins et al. 2019; Degrandi et al. 2020), DNA sequences (Benson et al. 2013), eukaryotic repetitive elements (Jurka et al. 2005), and nuclear genome sizes (Gregory et al. 2007).

Due to the great importance of genome size information (reviewed in Gregory 2005), a number of databases were created to assemble the available data on plants, animals, and fungi: the 
Plant DNA C-values Database, the Animal Genome Size Database, and the Fungal Genome Size Database (Gregory et al. 2007). Despite the increasing number of entries added to these databases over the years, studies involving bees are scarce. Only one study sampled a few representatives of all Apidae subfamilies, together with other hymenopterans, to study potential genome size constraints related to lifestyle (Ardila-Garcia et al. 2010). Despite an apparent general trend of small genomes reported in parasitic and social species (Johnston et al. 2004, 2007; Koshikawa et al. 2008), Ardila-Garcia et al. (2010) found that neither parasitism leads to small genomes nor non-parasitism results in the evolution of larger genomes, although both parasitoids and eusocial species exhibit significantly smaller genomes than those of non-parasitoid solitary species.

In addition, few studies have focused on the Meliponini tribe (Apinae), attempting to relate nuclear genome size with differences in heterochromatic patterns, finding a positive correlation between genome size and heterochromatin content in stingless bees (Lopes et al. 2009; Tavares et al. 2010, 2012). Still, some intriguing questions remain to be addressed, such as what types of sequences could be responsible for the differences in nuclear genome size among species, as well as the relationships with chromatin composition and structure, and evolution in bees.

Another relationship that has historically been discussed is the correlation between chromosome number and eusociality, with a higher chromosome number reported among social species in comparison with the lower numbers found in parasitic/solitary species (Sherman 1979; Templeton 1979; Anderson 1984; Gokhman 2009). To address this question, Ross et al. (2015) compared sister clades with different lifestyles among Hymenoptera and did not find strong support for this hypothesis, arguing the importance of increased recombination rates for social lifestyle evolution. Further investigation is needed to elucidate the importance of sociality for the evolution of these high recombination frequencies (Wilfert et al. 2007; Howard and Thorne 2010; Sirvio et al. 2011; Ross et al. 2015).

The first bee karyotype was described in 1913 from Osmia cornuta (Latreille, 1805) by
Armbruster (Kerr and Laidlaw 1956). Since then, around 200 bee species have been karyotyped. Taken together, these findings show that the chromosome number in bees varies from $n=3$ in Andrena togashii Tadauchi and Hirashima, 1984 to $n=28$ in Hylaeus sp.2 (Hoshiba and Imai 1993). A number of hypotheses have been proposed to explain this variation: (1) the polyploidy hypothesis proposes that numerical changes in the whole set of chromosomes are the main cytogenetic events responsible for the chromosomal variability in bees (Kerr 1952; Kerr 1969; Kerr and Silveira 1972). This hypothesis was based on the cytogenetic data available at time, and suggests that the chromosome number has doubled in some lineages. However, with accumulating information on several species with intermediate chromosome numbers, the polyploid hypotheses could no longer explain the observed numerical bee chromosomal variation; (2) The minimum interaction theory (MIT) postulates that the chromosome number increases over evolutionary time due to centric fissions to minimize deleterious interactions between chromosomes in the nuclei (Imai et al. 1986, 1988; Imai 1991; Hoshiba and Imai 1993; Imai et al. 1994). This hypothesis was based on the heterochromatin and chromosome morphology patterns, and has been the main theory used to explain chromosome number variation in hymenopterans; (3) the role of Robertsonian rearrangements and the importance of fusion events in bee evolution (Tavares et al. 2017; Travenzoli et al. 2019). This theory was based on metaanalyses mainly on the Meliponini tribe (Apinae), and the lack of concordance of some stingless bee chromosomal features to the MIT, broadening the bee karyotype evolution to a handful of cytogenetic rearrangements, and recognizing that generalizations should be made with caution.

To date, only one informal compilation of the available cytogenetic information regarding all Apidae subfamilies has been performed. Furthermore, it unfortunately contains some taxonomic misclassifications (Ross et al. 2015). Thus, in an attempt to assemble all the cytogenetic information published on bees, the Bee Chromosome database was created (www.bees.ufop.br). Whenever possible, nuclear genome size estimates (in picogram, pg) were also recorded. Since 
information dating back to 1913 was collected, we attempted to changes in species classification (original classifications are shown under the column "notes"). Considering the importance of cytogenetic studies for taxonomy, phylogeny, genetics, systematics, conservation, and evolution (Gokhman and Kuznetsova 2006; Potter and Deakin 2018), the aim of this database is to outline the advances that have been made in the field of bee cytogenetics over the last century.

\section{CYTOGENETIC DATA ASSEMBLY}

In order to assemble all cytogenetic information available on bees, we searched published papers for the following topics: haploid/diploid number, nuclear genome size, and classic/ molecular cytogenetic techniques. Keywords were also added to the search, such as "bees," "Apidae," subfamilies, and tribe names, in order to achieve more relevant and specific results. The search was performed on some of the main platforms, namely ISI Web of Knowledge, SCOPUS, and Google Scholar, as well as the references cited in any of the articles downloaded. All of the published manuscripts were downloaded and checked for the aforementioned information. Unpublished data, such as in academic theses and abstracts from conferences, were not recorded. The current species classification was based on the Moure catalog and on recent taxonomic papers that can be assessed online at http://moure.cria. org.br/catalogue?id=1 (catalog of bees) and http://www.itis.gov (Integrated Taxonomic Information System, ITIS).

The information was extracted manually from each manuscript and recorded in an Excel sheet using the following fields: species name (subfamily, tribe, genus, species), sample locality, haploid/diploid number, karyotype, nuclear haploid genome size (picograms pg), classic and molecular techniques available, and the respective references. Under "notes," some observations were explained, such as the presence of B chromosomes, changes in species classification, or if subgenera or subspecies were cited in the original articles. In this Excel sheet, each cell of the table represents a value, where the row A1 is the column title. The script that accesses this table and organizes the information to be displayed on the website was written in the programming language Python.

The karyotypic formula was presented as it was provided in the original paper, where some entries have the "Levan classification" and others have the "Imai classification" of the chromosomes. Levan et al. (1964) proposed a chromosome classification based on the arm ratio between the long and short arms, and classified them as metacentric (m), submetacentric (sm), subtelocentric (st), and acrocentric (a). On the other hand, Imai (1991) classified the chromosomes in metacentric $(\overline{\mathrm{M}})$, acrocentric $(\mathrm{A})$, or pseudo-acrocentric $\left(\mathrm{A}^{\mathrm{M}}\right)$, with a variety of forms depending on the position of the heterochromatin on the karyotype (e.g., $\mathrm{A}^{\mathrm{e}}, \mathrm{A}^{\mathrm{Mc}}$, $\left.\overline{\mathrm{M}}^{\mathrm{t}}, \overline{\mathrm{M}}^{\mathrm{cc}}, \overline{\mathrm{M}}^{\mathrm{i}}\right)$. Evidence of incorrect chromosome number designation was not included in the dataset, but is discussed later in this text. Differences among populations of the same species were regarded as individual entries in the database. All this information can be accessed at the permanent domain www.bees.ufop.br.

\section{DATASET ON THE APIDAE SUBFAMILIES}

By the time of the publication of this database (2020), there were 236 entries representing 56 genera across five Apidae subfamilies, whereas two subfamilies had no records (Melittinae and Stenotritinae). In the Andreninae subfamily, only A. togashii has been cytogenetically characterized so far, holding the record of the smallest bee chromosome number $(n=3)$ (Hoshiba and Imai 1993). Apinae has the largest number of entries (198), followed by Halictinae (19), Megachilinae (11), Collectinae (6), and Andreninae (2) (Figure 1). The discrepancy of entries observed in Apinae could be credited to the difficulties in collecting solitary species in contrast to the ease of spotting nests of social species, and the fact that many species are bred by beekeepers.

The dataset can be accessed for each subfamily, tribe, or genus, and each search result can be downloaded as a CSV file. The results are shown in the format of a table with all the cytogenetic information available in the columns 


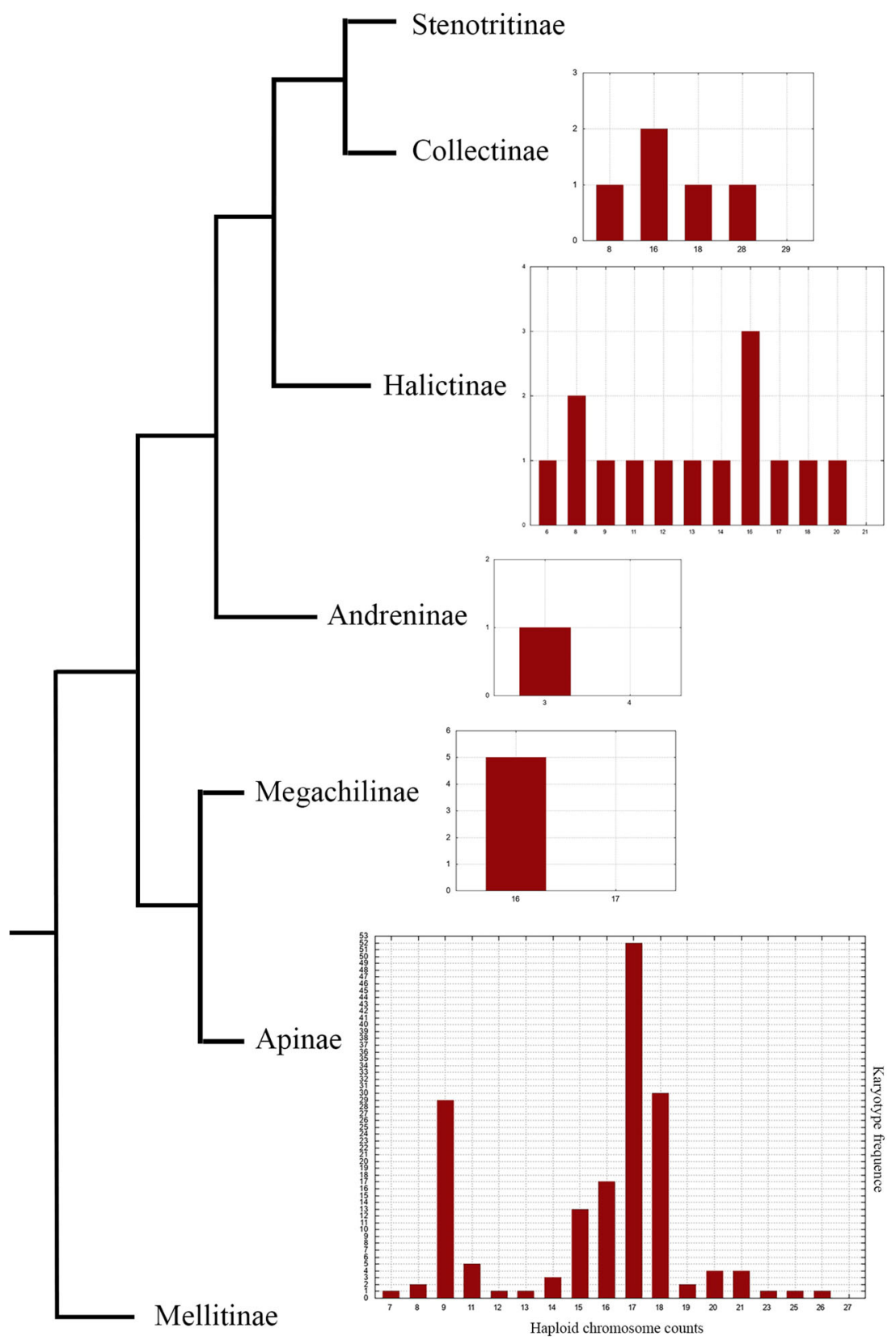

Figure 1. Phylogenetic relationships between Apidae subfamilies redrawn from Danforth et al. (2013) and the respective variation on the haploid chromosome number (Mellitinae and Stenotritinae have no cytogenetic records).

(Figure 2) or as a histogram of the frequency of the haploid number in each searched taxon (Figure 3), in which diploid $(2 n)$ values were converted to haploid $(n)$. The full dataset can be visualized under the name "Apidae family" as well as in the tab "Statistics" (Figure 4). This database will be kept up to date with the addition of new records by the authors but also by researchers abroad that are encouraged to use the tab "Submit." To report potential errors or 


\section{Cytogenetic data}

\begin{tabular}{|c|c|c|c|c|c|c|c|c|c|c|c|}
\hline Tribe & Species & $\begin{array}{l}\text { Sample } \\
\text { local }\end{array}$ & Country(ies) & Haploid(n) & Diploid(2n) & Karyotype & Notes & $\begin{array}{l}\text { Genome } \\
\text { size } \\
\text { (pg) }\end{array}$ & $\begin{array}{l}\text { Classic } \\
\text { cytogenetic } \\
\text { data }\end{array}$ & $\begin{array}{l}\text { Molecular } \\
\text { cytogenetic } \\
\text { data }\end{array}$ & References \\
\hline Colletini & $\begin{array}{l}\text { Colletes } \\
\text { babai }\end{array}$ & $\begin{array}{l}\text { Rifu, } \\
\text { Miyagi }\end{array}$ & Japan & 16 & 32 & $\begin{array}{l}\mathrm{k}=12 \mathrm{AM}+ \\
4 \mathrm{AMC}\end{array}$ & & & C-banding & & $\begin{array}{l}\begin{array}{l}\text { Hoshiba } \\
\text { and Imai }\end{array} \\
\underline{1993}\end{array}$ \\
\hline Colletini & $\begin{array}{l}\text { Colletes } \\
\text { esakii }\end{array}$ & $\begin{array}{l}\text { Daisen, } \\
\text { Tottori }\end{array}$ & Japan & 16 & & $\begin{array}{l}\mathrm{k}=6 \mathrm{AM}+ \\
9 \mathrm{AMC}+ \\
1 \mathrm{Ai}\end{array}$ & & & C-banding & & $\begin{array}{l}\text { Hoshiba } \\
\text { and Imai } \\
1993\end{array}$ \\
\hline Hylaeini & $\begin{array}{l}\text { Hylaeus } \\
\text { affinis }\end{array}$ & $\begin{array}{l}\text { Lake } \\
\text { Placid, } \\
\text { Florida }\end{array}$ & $\begin{array}{l}\text { United } \\
\text { States }\end{array}$ & & & & & 0.64 & & & $\frac{\frac{\text { Ardila- }}{\text { Garcia et }}}{\text { al. } 2010}$ \\
\hline Hylaeini & $\begin{array}{l}\text { Hylaeus } \\
\text { nippon }\end{array}$ & $\begin{array}{l}\text { Matsue, } \\
\text { Shimane }\end{array}$ & Japan & 8 & & $\begin{array}{l}k=1 A M i+ \\
4 M C+3 M\end{array}$ & & & C-banding & & $\begin{array}{l}\begin{array}{l}\text { Hoshiba } \\
\text { and Imai } \\
1993\end{array} \\
\end{array}$ \\
\hline Hylaeini & $\begin{array}{l}\text { Hylaeus } \\
\text { sp. } 1\end{array}$ & $\begin{array}{l}\text { Rifu, } \\
\text { Miyagi }\end{array}$ & Japan & 18 & & $\begin{array}{l}k=4 M C+ \\
8 M+6 M c c\end{array}$ & & & C-banding & & $\begin{array}{l}\text { Hoshiba } \\
\text { and Imai } \\
1993\end{array}$ \\
\hline Hylaeini & $\begin{array}{l}\text { Hylaeus } \\
\text { sp. } 2\end{array}$ & $\begin{array}{l}\text { Rifu, } \\
\text { Miyagi }\end{array}$ & Japan & 28 & & $\begin{array}{l}\mathrm{k}=25 \mathrm{AM}+ \\
1 \mathrm{AMC}+1 \mathrm{M} \\
+1 \mathrm{MCC}\end{array}$ & & & C-banding & & $\begin{array}{l}\text { Hoshiba } \\
\text { and Imai } \\
1993\end{array}$ \\
\hline
\end{tabular}

Figure 2. Example of the data generated in the Bee Chromosome database as a table containing all the cytogenetic information available from the Collectinae subfamily.

suggest improvements in the website, use the tab "Contact Us."
Only a few descriptions of chromosome number were not included in the database be-

\section{Histogram}

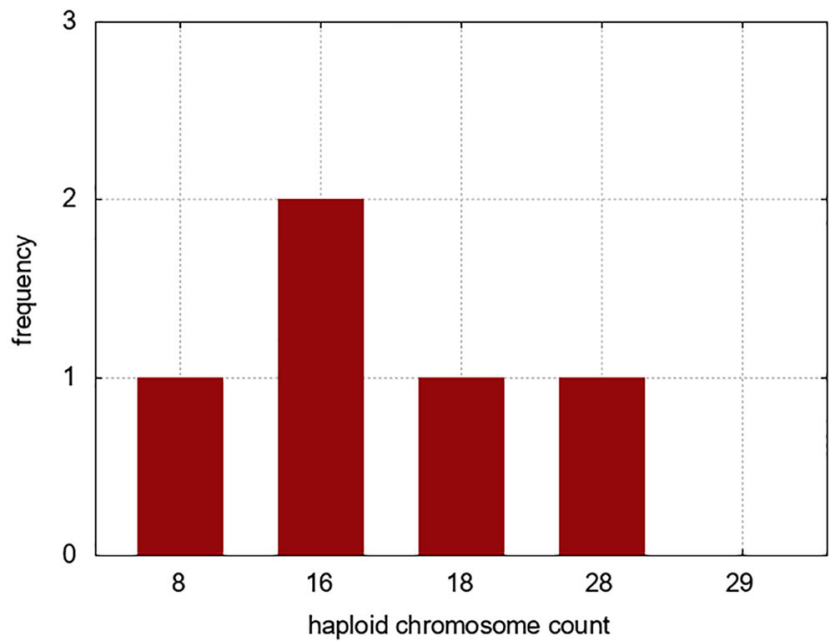

Figure 3. Example of the frequency histogram of the haploid chromosome count generated in the Bee Chromosome database for the Collectinae subfamily. Diploid $(2 n)$ values were converted to haploid $(n)$ values. 


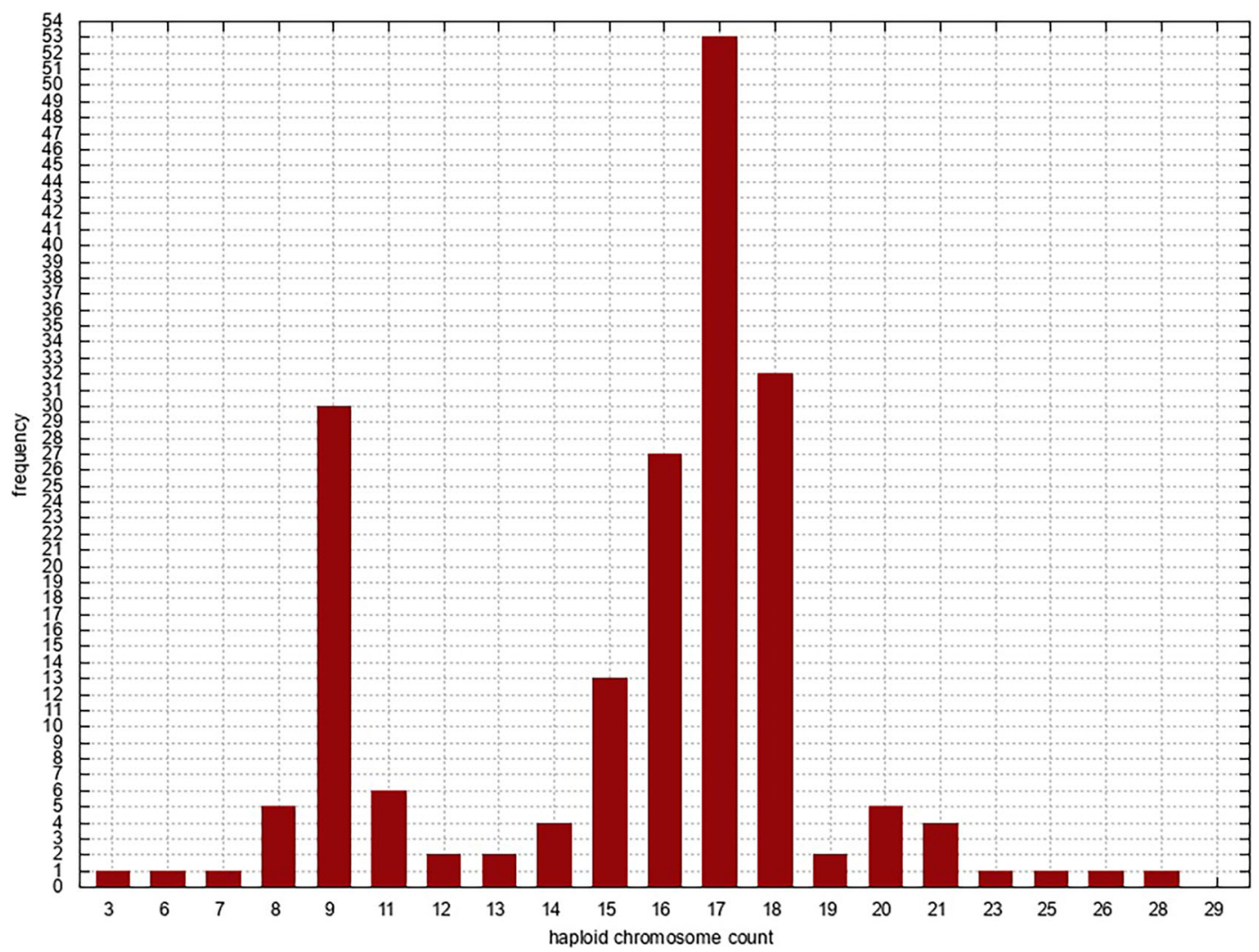

Figure 4. Frequency distribution of the haploid chromosome entries in the Bee Chromosome database in October 2020.

cause of incorrect chromosome counting: three species reported by Owen (1983) were corrected years later by Owen et al. (1995). Several species described by Kerr (1972) were later corrected in other publications (reviewed in Tavares et al. 2017). Studies performed before the 1980s used the squashing technique to obtain chromosomes, in contrast to the airdrying technique used more recently (see Imai et al. 1988), which is considered a better technique to count and visualize the morphology of chromosomes (Gokhman and Kuznetsova 2006). Many species described in the dataset have not been addressed in other studies since the first karyotype description (e.g., Meliponini Afrotropical); hence, the use of such information in future papers should require some caution, especially regarding descriptions based on papers without the images of the chromosomes (e.g., Kerr 1952; Kerr and Araújo 1957; Kerr and Silveira 1972) or with poor quality of the images (e.g., Kumbkarni 1965; Kerr 1972).

There were 68 entries regarding nuclear genome size in the database, which varied from $1 \mathrm{C}=0.19 \mathrm{pg}$ in Apis cerana Fabricius, 1793 to $1 \mathrm{C}=1.38 \mathrm{pg}$ in Melipona capixaba Moure and Camargo, 1995. Several methodological challenges still need to be addressed in this field, such as the standardization of the techniques and measurements. For instance, estimates vary from $1 \mathrm{C}=0.42 \mathrm{pg}$ to $1 \mathrm{C}=0.62 \mathrm{pg}$ in Bombus terrestris (Linnaeus, 1758) depending on the technique used (reviewed in Stolle et al. 2011). Other important topics for further study include the 
variations in genome size observed among populations from different geographical locations (see Ardila-Garcia et al. 2010; Cardoso et al. 2018b), and between males and females (see Tavares et al. 2012), as well as the constraints related to developmental complexity (see Gregory 2002).

\section{CONCLUSIONS AND PERSPECTIVES}

Until the 1990s, cytogenetic research was restricted to the description of chromosome numbers. Since then, advances in techniques (mainly molecular cytogenetics) have allowed for the development of more elaborate studies, testing different hypotheses regarding the chromosomal evolution in bees (e.g., Piccoli et al. 2018; Santos et al. 2018; Travenzoli et al. 2019; Cunha et al. 2020; Pereira et al. 2020). However, these studies focused on the Meliponini tribe, and are still far from encompassing the current diversity of bees.

Karyotype rearrangements and nuclear genome size changes can result in reproductive isolation, contributing to diversification and speciation (Schubert and Lysak 2011; Ferree and Prasad 2012; Cardoso et al. 2018b). Collecting this information in an online public database will facilitate access to researchers focused on specific groups, as well as allow for the visualization of general patterns for the Apidae family and highlight existing knowledge gaps.

Recently, similar efforts were made to organize the cytogenetic data available on ants: the Ant Chromosome database ACdb (Cardoso et al. 2018a, www.ants.ufop.br). There are over 15,000 ant species described worldwide (Bolton et al. 2007), only 520 of which have been karyotyped (reviewed in Cardoso et al. 2018a). Together, we share a common goal to contribute to future studies involving systematics, evolution, and chromosome biology in the order Hymenoptera.

\section{ACKNOWLEDGMENTS}

The authors wish to thank Gustavo de Sousa Cunha and Haroldo Gambini Santos for the computational support during the development of the script of the site.

\section{AUTHORS' CONTRIBUTION}

All authors contributed to the study conception and design. Literature review and data collection were performed by MSC. LAOC and MSC checked species classification. The first draft of the manuscript was written by MSC and DCC. All authors commented on previous versions and approved the final manuscript.

\section{FUNDING}

The authors also wish to thank the "Conselho Nacional de Desenvolvimento Científico e Tecnológico (CNPq)," "Coordenação de Aperfeiçoamento de Pessoal de Nível Superior (CAPES)," and "Fundação de Amparo à Pesquisa do Estado de Minas Gerais (FAPEMIG)" for the financial support.

\section{DATA AVAILABILITY}

The datasets generated during the current study are available in the database here presented at www.bees.ufop.edu.br. Any further data are available from the corresponding authors on reasonable request.

\section{COMPLIANCE WITH ETHICAL STANDARDS}

Conflict of interest The authors declare that they have no conflict of interest.

\section{Ethical approval Not applicable}

La base de données sur les chromosomes de l'abeille (Hymenoptera : Apidae).

Évolution chromosomique / nombre de chromosomes / cytogénétique / formule caryotypique / taille du génome.

Die Bienenchromosomen Datenbasis (Hymenoptera: Apidae).

Chromosomenevolution / Chromosomenzahl / Zytogenetik / karyotypische Formel / Genomgrösse. 


\section{REFERENCES}

Anderson, M. (1984) The evolution of eusociality. Annu. Rev. Ecol. Syst. 15 (1), 165-189

Ardila-Garcia, A. M., Umphrey, G. J., Gregory, T. R. (2010) An expansion of the genome size dataset for the insect order Hymenoptera, with a first test of parasitism and eusociality as possible constraints. Insect Mol. Biol. 19 (3), 337-346

Benson, D. A., Cavanaugh, M., Clark, K., KarschMizrachi, I., Lipman, D. J., Ostell, J., Sayers, E. W. (2013) GenBank. Nucleic Acids Res. 41 (D1), D36D42

Berrar, D., Dublizky, W., Solinas-Toldo, S., Buloshevska, S., Granzow, M., Conrad, C., Kalla, J., Lichter, P., Eils, R. (2001) A database system for comparative genomic hybridization analysis. IEEE Eng. Med. Biol. Mag. 20 (4), 75-83

Bolton, B., Alpert, G., Ward, P. S. Naskrecki, P. (2007) Bolton's catalogue of ants of the world: 1758-2005. Harvard University Press, Cambridge

Cardoso, D. C., Santos, H. G., Cristiano, M. P. (2018a) The Ant Chromosome Database (ACdb): an online resource for ant (Hyrmenoptera: Formicidae) chromosome researchers. Myrmecol. News 27, 87-91

Cardoso, D. C., Heinze, J., Moura, M. N., Cristiano, M. P. (2018b) Chromosomal variation among populations of a fungus-farming ant: implications for karyotype evolution and potential restriction to gene flow. BMC Evol. Biol. 18 (1), 146

Cunha, M. S., Campos, L. A. O., Lopes, D. M. (2020). Insights into the heterochromatin evolution in the genus Melipona (Apidae: Meliponini). Insectes Soc. 67, 391-398

D’Ambrosio, U., Alonso-Lifante, M. P., Ferradás, K. B., Kovarik, A., Mas de Xaxars, G., Garcia, S. (2017) Bchrom: A database on B-chromosomes of plants, animals and fungi. New Phytol. 216 (3), 635-642

Danforth, B. N., Cardinal, S., Praz, C., Almeida, E. A., Michez, D. (2013) The impact of molecular data on our understanding of bee phylogeny and evolution. Annu. Rev. Entomol. 58, 57-78

Degrandi, T. M., Barcellos, S. A., Costa, A. L., Garnero, A. D., Hass, I., Gunski, R. J. (2020) Introducing the Bird Chromosome Database: An overview of cytogenetic studies in birds. Cytogenet. Genome Res. 160, 199-205

Fayyad, U., Piatetsky-Shapiro, G., Smyth, P. (1996) From data mining to knowledge discovery in databases. AI Mag. 17 (3), 37-54

Ferree, P. M., Prasad, S. (2012) How can satellite DNA divergence cause reproductive isolation? Let us count the chromosomal ways. Genet. Res. Int. 2012, 11

Gokhman, V. E. (2009) Karyotypes of Parasitic Hymenoptera. Springer, Berlin

Gokhman, V. E., Kuznetsova, V. G. (2006) Comparative insect karyology: current state and applications. Entomol. Rev. 86 (3), 352-368
Gregory, T. R. (2002) Genome size and developmental complexity. Genetica 115 (1), 131-146

Gregory, T. R. (2005) The evolution of the genome. Elsevier Academic Press

Gregory, T. R., Nicol, J. A., Tamm, H., Kullman, B., Kullman, K., Leitch, I. J., Murray, B.G., Kapraun, D.F., Greilhuber, J., Bennett, M. D. (2007) Eukaryotic genome size databases. Nucleic Acids Res. 35 (1), 332-338

Hoshiba, H., Imai, H. (1993) Chromosome evolution of bees and wasps (Hymenoptera, Apocrita) on the basis of C-banding pattern analyses. Jpn. J. Ent. 61 (3), 465492

Howard, K. J., Thorne, B. L. (2010) Eusocial evolution in termites and Hymenoptera, in Bignell, D. E., Roisin, Y., Lo, N. (Eds.), Biology of termites: a modern synthesis. Springer, Dordrecht, pp. 97-132

Imai, H. T. (1991) Mutability of constitutive heterochromatin (C-bands) during eukaryotic chromosomal evolution and their cytological meaning. Jpn. J. Genet. 66 (5), 635-661

Imai, H. T., Maruyama, T., Gojobori, T., Inoue, Y., Crozier, R. H. (1986) Theoretical bases for karyotype evolution. 1. The minimum-interaction hypothesis. Am. Nat. 128 (6), 900-920

Imai, H. T., Taylor, R. W., Crosland, M. W., Crozier, R. H. (1988) Modes of spontaneous chromosomal mutation and karyotype evolution in ants with reference to the minimum interaction hypothesis. Jpn. J. Genet. 63 (2), $159-185$

Imai, H. T., Taylor, R. W., Crozier, R. H. (1994) Experimental bases for the minimum interaction theory. I. Chromosome evolution in ants of the Myrmecia pilosula species complex (Hymenoptera: Formicidae: Myrmeciinae). Jpn. J. Genet. 69 (2), 137-182

Johnston, J. S., Ross, L. D., Beani, L., Hughes, D. P., Kathirithamby, J. (2004) Tiny genomes and endoreduplication in Strepsiptera. Insect Mol. Biol. 13 (6), 581-585

Johnston, J. S., Yoon, K. S., Strycharz, J. P., Pittendrigh, B. R., Clark, J. M. (2007) Body lice and head lice (Anoplura: Pediculidae) have the smallest genomes of any hemimetabolous insect reported to date. J. Med. Entomol. 44 (6), 1009-1012

Jurka, J., Kapitonov, V. V., Pavlicek, A., Klonowski, P., Kohany, O., Walichiewicz, J. (2005) Repbase Update, a database of eukaryotic repetitive elements. Cytogeneti. Genome Res. 110 (1-4), 462-467

Kapheim, K. M., Pan, H., Li, C., Salzberg, S. L., Puiu, D., Magoc, T., et al. (2015) Genomic signatures of evolutionary transitions from solitary to group living. Science 348 (6239), 1139-1143

Kerr, W. E. (1952) A variação do número de cromossomos na evolução dos Hymenoptera. Sci. Genet. 4 (3), 182190

Kerr, W. E. (1969) Some aspects of the evolution of social bees (Apidae). Evol. Biol. 3, 119-175 
Kerr, W. E. (1972) Numbers of chromosomes in some species of bees. J. Kansas Entomol. Soc. 45 (1), 111122

Kerr, W. E., Laidlaw, H. H. (1956) General genetics of bees. Adv. Genet. 8, 109-153

Kerr, W. E., Araújo, V. P. (1957) Contribuição ao estudo citológico dos Apoidea. I. Espermatogênese em três espécies africanas. Garcia de Orta, 5 (3), 431-433

Kerr, W. E., Silveira, Z. V. D. (1972) Karyotypic evolution of bees and corresponding taxonomic implications. Evolution 26 (2), 197-202

Koshikawa, S., Miyazaki, S., Cornette, R., Matsumoto, T., Miura, T. (2008) Genome size of termites (Insecta, Dictyoptera, Isoptera) and wood roaches (Insecta, Dictyoptera, Cryptocercidae). Naturwissenschaften 95 (9), 859-867

Kumbkarni, C. G. (1965) Cytological Studies in Hymenoptera: Part II: Cytology of parthenogenesis in the carpenter-bee, Xylocopa fenesterata Fabre. Cytologia 30 (2), 222-228

Levan, A., Fredga, K., Sandberg, A. A. (1964) Nomenclature for centromeric position on chromosomes. Hereditas 52 (2), 201-220

Lopes, D. M., Carvalho, C. R., Clarindo, W. R., Praça, M. M., Tavares, M. G. (2009) Genome size estimation of three stingless bee species (Hymenoptera, Meliponinae) by flow cytometry. Apidologie 40 (5), 517-523

Melo, G. A., Gonçalves, R. B. (2005). Higher-level bee classifications (Hymenoptera, Apoidea, Apidae sensu lato ). Rev. Bras. Zool. 22 (1), 153-159

Michener, C. D. (2007) Bee taxa and categories, in Michener, C. D. (Eds.), The Bees of the World. 2nd Ed. The Johns Hopkins University Press, Baltimore, pp 66-75

Moure, J. S., Urban, D. Melo, G. A. (2007) Catalogue of bees (Hymenoptera, Apoidea) in the Neotropical Region. Sociedade Brasileira de Entomologia, Curitiba. Available online at http://moure.cria.org. br/catalogue?id=1. Accessed Apr 2020

Owen, R. E. (1983) Chromosome numbers of 15 North American bumble bee species (Hymenoptera, Apidae, Bombini). Can. J. Genet. Cytol. 25 (1), 26-29

Owen, R. E., Richards, K. W., Wilkes, A. (1995) Chromosome numbers and karyotypic variation in bumble bees (Hymenoptera: Apidae; Bombini). J. Kansas Entomol. Soc. 68 (3), 290-302

Pereira, J. A., Salomão, T. M. F., Lopes, D. M. (2020) Different repetitive DNA sequences make up heterochromatin in Meliponini. Apidologie https://doi. org/10.1007/s13592-020-00766-1

Perkins, R. D., Gamboa, J. R., Jonika, M. M., Lo, J., Shum, A., Adams, R. H., Blackmon, H. (2019) A database of amphibian karyotypes. Chromosome Res. 27 (4), 313319

Piccoli, M. C. A., Bardella, V. B., Cabral-de-Mello, D. C. (2018) Repetitive DNAs in Melipona scutellaris (Hymenoptera: Apidae: Meliponidae): chromosomal distribution and test of multiple heterochromatin amplification in the genus. Apidologie 49 (4), 497-504

Potter, S., Deakin, J. E. (2018) Cytogenetics: an important inclusion in the conservation genetics toolbox. Pac. Conserv. Biol. 24 (3), 280-288

Ross, L., Blackmon, H., Lorite, P., Gokhman, V. E., Hardy, N. B. (2015) Recombination, chromosome number and eusociality in the Hymenoptera. J. Evolution. Biol. 28 (1), 105-116

Roubik, D. W., Heard, T. A., Kwapong, P. (2018) Stingless bee colonies and pollination, in Roubik, D. W. (Ed.), The pollination of cultivated plants: A compendium for practitioners. Volume 2. Smithsonian Tropical Research Institute, pp. 39-64

Santos, J. M. D., Diniz, D., Rodrigues, T. A. S., Cioffi, M. D. B., Waldschmidt, A. M. (2018) Heterochromatin distribution and chromosomal mapping of microsatellite repeats in the genome of Frieseomelitta stingless bees (Hymenoptera: Apidae: Meliponini). Fla. Entomol. 101 (1), 33-39

Schubert, I., Lysak, M. A. (2011) Interpretation of karyotype evolution should consider chromosome structural constraints. Trends Genet. 27 (6), 207-216.

Sedivy, C., Dorn, S., Müller, A. (2013) Evolution of nesting behaviour and kleptoparasitism in a selected group of osmiine bees (Hymenoptera: Megachilidae). Biol. J. Linn. Soc. 108 (2), 349-360

Shell, W. A., Rehan, S. M. (2018) Behavioral and genetic mechanisms of social evolution: insights from incipiently and facultatively social bees. Apidologie 49 (1), 13-30

Sherman, P. W. (1979) Insect chromosome numbers and eusociality. Amer. Nat. 113 (6), 925-935

Sirvio, A., Johnston, J. S., Wenseleers, T., Pamilo, P. (2011) A high recombination rate in eusocial Hymenoptera: evidence from the common wasp Vespula vulgaris . BMC Genet. 12 (1), 95

Stolle, E., Wilfert, L., Schmid-Hempel, R., SchmidHempel, P., Kube, M., Reinhardt, R., Moritz, R. F. (2011) A second generation genetic map of the bumblebee Bombus terrestris (Linnaeus, 1758) reveals slow genome and chromosome evolution in the Apidae. BMC Genomics 12 (1), 48

Tavares, M. G., Carvalho, C. R., Soares, F. A. F. (2010) Genome size variation in Melipona species (Hymenoptera: Apidae) and sub-grouping by their DNA content. Apidologie 41 (6), 636-642

Tavares, M. G., Carvalho, C. R., Soares, F. A. F., Campos, L. A. O. (2012) Genome size diversity in stingless bees (Hymenoptera: Apidae, Meliponini). Apidologie 43 (6), 731-736

Tavares, M. G., Lopes, D. M., Campos, L. A. O. (2017) An overview of cytogenetics of the tribe Meliponini (Hymenoptera: Apidae). Genetica 145 (3), 241-258

Templeton, A. R. (1979) Chromosome number, quantitative genetics and eusociality. Amer. Nat. 113 (6), 937-941

Travenzoli, N. M., Cardoso, D. C., Werneck, H. D. A., Fernandes-Salomão, T. M., Tavares, M. G., Lopes, D. 
M. (2019) The evolution of haploid chromosome numbers in Meliponini. PloS One 14 (10), e0224463

Vulto-van Silfhout, A. T., van Ravenswaaij, C. M., HehirKwa, J. Y., Verwiel, E. T., Dirks, R., van Vooren, S., Schinzel, A., de Vries, B. B. A., de Leeuw, N. (2013) An update on ECARUCA, the European cytogeneticists association register of unbalanced chromosome aberrations. Eur. J. Med. Genet. 56 (9), 471-474
Wilfert, L., Gadau, J., Schmid-Hempel, P. (2007) Variation in genomic recombination rates among animal taxa and the case of social insects. Heredity 98 (4), 189-197

Publisher's note Springer Nature remains neutral with regard to jurisdictional claims in published maps and institutional affiliations. 